\title{
Stress-induced chaperones: a first line of defense against the powerful oxidant hypochlorous acid [version 1; peer review: 4
}

\section{approved]}

\author{
Camille V. Goemans¹, Jean-François Collet (iD2 \\ ${ }^{1}$ European Molecular Biology Laboratory, Meyerhofstrasse 1, 69117, Heidelberg, Germany \\ ${ }^{2}$ de Duve Institute, UCLouvain, Avenue Hippocrate 75, 1200 Brussels, Belgium
}

V1 First published: 23 Sep 2019, 8(F1000 Faculty Rev):1678
https://doi.org/10.12688/f1000research.19517.1

Latest published: 23 Sep 2019, 8(F1000 Faculty Rev):1678

https://doi.org/10.12688/f1000research.19517.1

\section{Abstract}

Hypochlorous acid ( $\mathrm{HOCl}$; bleach) is a powerful weapon used by our immune system to eliminate invading bacteria. Yet the way $\mathrm{HOCl}$ actually kills bacteria and how they defend themselves from its oxidative action have only started to be uncovered. As this molecule induces both protein oxidation and aggregation, bacteria need concerted efforts of chaperones and antioxidants to maintain proteostasis during stress. Recent advances in the field identified several stress-activated chaperones, like Hsp33, RidA, and CnoX, which display unique structural features and play a central role in protecting the bacterial proteome during $\mathrm{HOCl}$ stress.

\section{Keywords}

oxidative stress, bleach, polyphosphate, bacteria, protein folding, chaperone, holdase, chlorination

\section{Open Peer Review \\ Approval Status \\ 1 \\ 23 \\ 3 \\ version 1 \\ 23 Sep 2019 \\ Faculty Reviews are review articles written by the prestigious Members of Faculty Opinions. The articles are commissioned and peer reviewed before publication to ensure that the final, published version is comprehensive and accessible. The reviewers who approved the final version are listed with their names and affiliations.}

1. Lars I. Leichert, Ruhr University Bochum, Bochum, Germany

2. Michael J. Gray, University of Alabama at Birmingham, Birmingham, USA

3. Haike Antelmann, Freie Universität Berlin, Berlin, Germany

4. Ursula Jakob, University of Michigan,, Ann Arbor, USA

Any comments on the article can be found at the end of the article. 
Corresponding authors: Camille V. Goemans (camille.goemans@embl.de), Jean-François Collet (jfcollet@uclouvain.be)

Author roles: Goemans CV: Writing - Original Draft Preparation, Writing - Review \& Editing; Collet JF: Writing - Original Draft Preparation, Writing - Review \& Editing

Competing interests: No competing interests were disclosed.

Grant information: CVG is a European Molecular Biology Organization (EMBO) post-doctoral fellow. This work was funded by grants from the Fonds de la Recherche Scientifique - FNRS for the Fund for Strategic Fundamental Research (FRFS)- Walloon Excellence in Lifesciences and Biotechnology (WELBIO) under grant number WELBIO-CR-2015A-03 (http://www.welbio.org).

The funders had no role in study design, data collection and analysis, decision to publish, or preparation of the manuscript.

Copyright: @ 2019 Goemans CV and Collet JF. This is an open access article distributed under the terms of the Creative Commons Attribution License, which permits unrestricted use, distribution, and reproduction in any medium, provided the original work is properly cited.

How to cite this article: Goemans CV and Collet JF. Stress-induced chaperones: a first line of defense against the powerful oxidant hypochlorous acid [version 1; peer review: 4 approved] F1000Research 2019, 8(F1000 Faculty Rev):1678

https://doi.org/10.12688/f1000research.19517.1

First published: 23 Sep 2019, 8(F1000 Faculty Rev):1678 https://doi.org/10.12688/f1000research.19517.1 


\section{Introduction}

Like all aerobic organisms, bacteria naturally produce reactive oxygen species (ROS) as metabolic by-products, for instance during electron transfer in the respiratory chain. The addition of one electron to $\mathrm{O}_{2}$ leads to the production of the superoxide radical $\left(\mathrm{O}_{2}^{-}\right)$, a toxic compound, which dismutates to form hydrogen peroxide $\left(\mathrm{H}_{2} \mathrm{O}_{2}\right)$ and molecular oxygen $\left(\mathrm{O}_{2}\right)$ either spontaneously or via catalysis by superoxide dismutases ${ }^{1-3}$. $\mathrm{H}_{2} \mathrm{O}_{2}$ can then react with ferrous iron to generate more reactive hydroxyl radicals $\left({ }^{\circ} \mathrm{OH}\right)$ by the Fenton reaction. These oxidizing molecules can damage cellular components including DNA, membrane lipids, and proteins, which can lead to cell death. Therefore, bacteria have evolved defense mechanisms, which include enzymes, such as catalases and peroxiredoxins, that directly react with ROS to convert them to harmless products, and repair enzymes, such as thioredoxins and methionine sulfoxide reductases, that catalyze the reduction of oxidized amino acids in damaged proteins. For more information on the mechanisms that allow bacteria to cope with oxidants and rescue oxidatively damaged proteins, we refer the reader to a recent review in which we discuss the role of the thioredoxin and glutaredoxin systems and highlight the importance of protein repair in bacterial physiology and virulence ${ }^{4}$.

Because of their toxicity, it is not surprising that the immune system of multicellular eukaryotes uses ROS as weapons to kill bacteria. When bacteria enter a tissue, the inflammatory response is turned on and phagocytes (neutrophils and macrophages) are recruited to the site of infection ${ }^{5}$. These cells, whose cytoplasm is filled with lysosomal granules containing a variety of bactericidal and digestive enzymes ${ }^{6,7}$, are able to engulf bacteria. After phagocytosis, the phagosome and the granules fuse, forming a phagolysosome $e^{6,7}$. Then, high levels of ROS $\left(\mathrm{O}_{2}{ }^{-}\right.$and $\left.\mathrm{H}_{2} \mathrm{O}_{2}\right)$ are produced in a phenomenon known as "oxidative burst" ${ }^{-8}$, strongly contributing to the killing of the bacterium.

\section{Hypochlorous acid, an oxidative weapon to combat invading bacteria}

In neutrophils, ROS production induces the release of myeloperoxidase (MPO), a glycoprotein stored in the phagocyte granules, into the phagolysosome. This enzyme converts $\mathrm{H}_{2} \mathrm{O}_{2}$ and chloride into hypochlorous acid $(\mathrm{HOCl})^{5}$, a strong oxidant $\left(\mathrm{E}^{0},\left[\mathrm{HOCl} / \mathrm{Cl}^{-}\right]=1.28 \mathrm{~V}\right)$ that is also the active ingredient of household bleach, the most widely used disinfectant. $\mathrm{HOCl}$ is extremely effective and reacts with most macromolecules, including lipids, cholesterol, NADH, nucleotides, and proteins ${ }^{9-11}$. In contrast to $\mathrm{H}_{2} \mathrm{O}_{2}$, which can diffuse through membranes $^{12}$ and has a substantially longer lifetime $\left(10 \mu \mathrm{s} ;{ }^{13}\right)$, $\mathrm{HOCl}$ acts rapidly and locally, with a lifetime of $\sim 0.1 \mu \mathrm{s}^{14}$ and a short diffusion length in vivo $(0.03 \mu \mathrm{m}$ when it reacts with cysteines and methionines ${ }^{15}$ ). Thus, by catalyzing the conversion of long-lived, diffusible $\mathrm{H}_{2} \mathrm{O}_{2}$ into locally confined $\mathrm{HOCl}$, MPO contributes to the prevention of collateral tissue damage during oxidative burst, allowing the specific targeting of the engulfed bacterial pathogen ${ }^{14}$.

\section{Proteins are favorite $\mathrm{HOCl}$ targets}

Although $\mathrm{HOCl}$ targets all cellular components, proteins, because of their reactivity and high abundance, are thought to be its primary target. The oxidation of amino acid side-chains in proteins (Figure 1) can cause the loss of secondary or tertiary structure, thereby impacting protein stability and activity. $\mathrm{HOCl}$ reacts extremely quickly $\left(\mathrm{k} \approx 3 \times 10^{7} \mathrm{M}^{-1} \cdot \mathrm{s}^{-1}\right)$ with sulfur-containing residues (cysteines and methionines) $)^{10,11,16}$. Cysteine thiols are first rapidly chlorinated to form a sulfenyl chloride, an unstable intermediate that can react with water to form a sulfenic acid (R-SOH) (Figure 1). Most sulfenic acids are highly unstable (half-life in minutes ${ }^{17}$ ) and either react with a cysteine thiol present in the vicinity to form a disulfide, whose formation is in principle reversible by the action of an oxidoreductase like thioredoxin ${ }^{18}$, or are further oxidized to sulfinic $\left(\mathrm{R}-\mathrm{SO}_{2} \mathrm{H}\right)$ and sulfonic $\left(\mathrm{R}-\mathrm{SO}_{3} \mathrm{H}\right)$ acids (Figure 1$)$, two irreversible modifications that typically cause protein inactivation and degradation. Degrossoli and co-workers showed that exposure of bacteria to the oxidant mixture released during phagocytosis causes a rapid and massive oxidation of thiols ${ }^{19,20}$. By taking advantage of fluorescent redox-sensitive protein probes expressed by the engulfed bacteria, they highlighted the critical role of MPO-generated $\mathrm{HOCl}$ in the toxic oxidizing cocktail released by immune cells ${ }^{19}$.

Methionines can be oxidized to methionine sulfoxides (Met-SO), and this oxidation is likely to play a critical role in the bactericidal action of $\mathrm{HOCl}$, as strains lacking methionine sulfoxide reductases, enzymes that reduce methionine sulfoxides back to methionine, become more sensitive to $\mathrm{HOCl}^{21}$. In line with this idea, we recently identified an enzymatic system expressed in the cell envelope of Gram-negative bacteria that participates in the defense mechanisms against $\mathrm{HOCl}$ by reducing oxidized methionine residues in this compartment ${ }^{22}$. This system involves the molybdenum-containing enzyme MsrP and the hemebinding membrane protein MsrQ and uses electrons from the respiratory chain for methionine rescue. Remarkably, MsrP and MsrQ are specifically induced by $\mathrm{HOCl}$ in Escherichia coli, and not by $\mathrm{H}_{2} \mathrm{O}_{2}$, which further highlights the physiological need for cellular systems devoted to the defense against $\mathrm{HOCl}^{22}$.

In addition to sulfur-containing residues, primary (Figure 1) and secondary amines (not shown) are also susceptible to $\mathrm{HOCl}$, which chlorinates them to form chloramines $\left(\mathrm{k} \approx 10^{3}-10^{5} \mathrm{M}^{-1} \cdot \mathrm{s}^{-1}\right)^{10,11,16}$. Tryptophan is also thought to react with $\mathrm{HOCl}$ to form 2-oxindole, but how these molecules form remains unclear (Figure 1) ${ }^{10,11}$. The imidazole ring of histidine reacts with $\mathrm{HOCl}$ to form a short-lived chloramine, which rapidly transfers its chlorine group to another amine. Finally, the chlorination of tyrosine into 3-chlorotyrosine is a marker used to detect HOCl-induced damage (Figure 1) ${ }^{10,11}$.

\section{Stress-activated chaperones protect bacteria against $\mathrm{HOCl}$-induced protein aggregation}

The mechanism by which $\mathrm{HOCl}$ contributes to bacterial killing in the phagolysosome is not fully understood ${ }^{5}$. However, it is thought to be a combination of events including oxidation-induced protein aggregation $^{23}$ and a drastic decrease in cellular ATP caused by the inactivation of the $\mathrm{F}_{1}$-ATP synthase, loss of glucose respiration, and the formation of polyphosphate (PolyP) ${ }^{24}$. The bactericidal activity of $\mathrm{HOCl}$ can also be explained by the loss of activity of GroEL (Hsp60), an essential chaperone inactivated upon $\mathrm{HOCl}$ treatment ${ }^{25,26}$. 


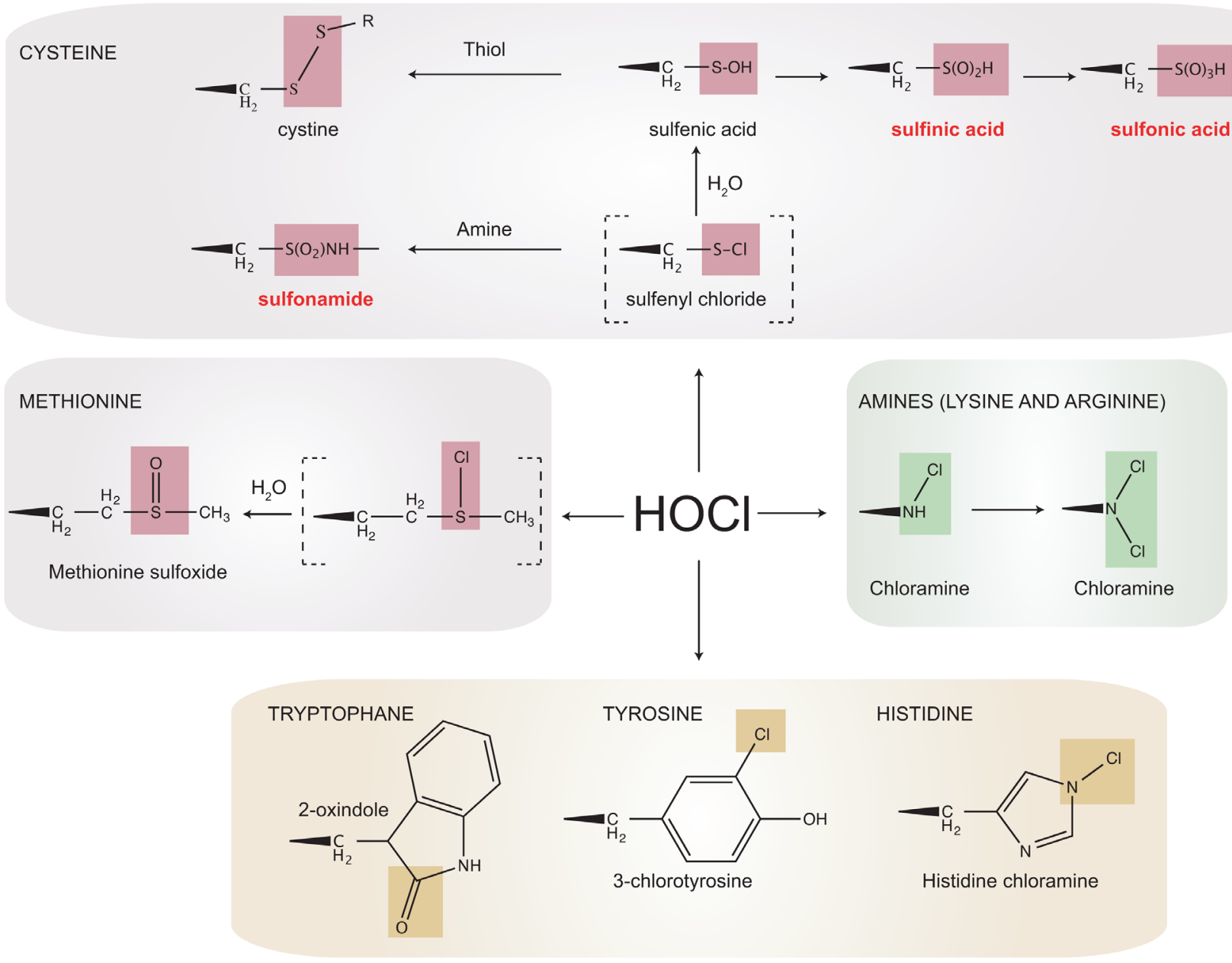

Figure 1. Side-chain modifications observed during hypochlorous acid $(\mathbf{H O C l})$ stress. $\mathrm{HOCl}$ modifies the side-chains of several amino acids. Reaction with the thiol group of cysteine residues leads to the formation of an unstable sulfenyl chloride. Sulfenyl chloride quickly reacts with water to form a sulfenic acid or with primary and secondary amines to form sulfonamide crosslinks, which are irreversible. Sulfenic acids can be reduced back to a thiol by the cytoplasmic reducing systems, be further oxidized to sulfinic or sulfonic acids that are irreversible and lead to protein inactivation and degradation, or react with another thiol to form disulfide bonds. Irreversibly oxidized forms are indicated in red. $\mathrm{HOCl}$ also reacts with methionine residues to form methionine sulfoxides. Primary and secondary amines (lysine and arginine) are the second targets of $\mathrm{HOCl}$ in proteins, which chlorinates them to form chloramines (the secondary amine of arginine is not shown). The imidazole ring of histidine reacts with $\mathrm{HOCl}$ to form a short-lived chloramine, which rapidly transfers its chlorine group to another amine. Tryptophan reacts with $\mathrm{HOCl}$ to form 2-oxindole while reaction of $\mathrm{HOCl}$ with tyrosine forms 3-chlorotyrosine.

In the last decade, important insights into the mechanisms used by bacteria to mount effective, often complex responses against $\mathrm{HOCl}$ have been obtained. For instance, transcription factors that specifically respond to $\mathrm{HOCl}$ have been described in E. coli and other bacteria ${ }^{27}$. They include HypT, which is activated through methionine oxidation ${ }^{28,29}$, and NemR, which is activated via cysteine oxidation. Furthermore, three $\mathrm{HOCl}-$ activated chaperones have been identified and shown to be important during $\mathrm{HOCl}$ stress. These chaperones are ATP-independent holdases, i.e. chaperones that prevent protein aggregation by binding unfolded proteins but do not promote protein refolding, and thus function during $\mathrm{HOCl}$ stress, when the ATP-dependent foldases, i.e. chaperones actively promoting protein refolding, are inactive (Figure 2). In the following sections, we will briefly describe $\mathrm{HOCl}$-activated chaperones and explain how they are activated under conditions that inactivate most other proteins ${ }^{30}$.

\section{Hsp33}

The first HOCl-activated chaperone identified was Hsp33, a protein which was recently described to work, under normal conditions, as an unfoldase/aggregase transferring EF-Tu to the Lon protease for degradation ${ }^{31}$. However, when exposed to $\mathrm{HOCl}$, Hsp33 is quickly transformed into a holdase through the oxidation of a redox switch involving four conserved, zinc-binding cysteine residues $^{32-38}$. Oxidation of this redox switch induces structural changes in Hsp33 that now exposes hydrophobic surfaces and can interact with unfolded proteins ${ }^{32-38}$. Upon 


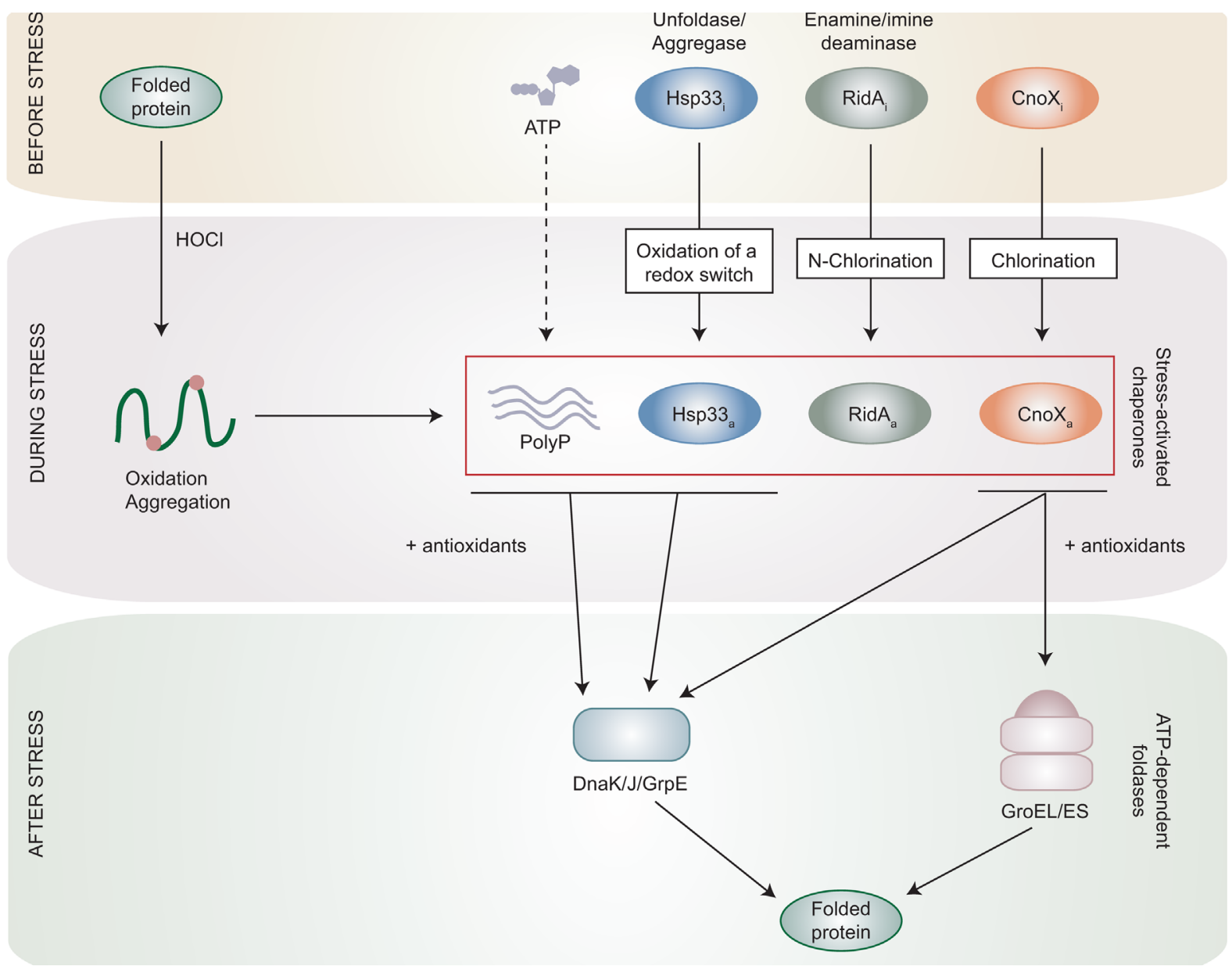

Figure 2. Protein protection network during hypochlorous acid (HOCl) stress. Upon $\mathrm{HOCl}$ stress, most proteins become oxidized and lose their three-dimensional structure, ultimately leading to their aggregation. In parallel, the oxidation or chlorination of stress-induced holdases (Hsp33, RidA, and CnoX) activates them upon HOCl stress, which allows them to bind and protect their substrates. Polyphosphate (PolyP), a chemical chaperone synthesized from ATP, has also been shown to bind unfolded proteins during stress. After stress, when the ATP pool is replenished and oxidative stress relieved, these stress-induced holdases cooperate with antioxidants to transfer their substrates to either DnaK/J/GrpE or GroEL/ES for proper refolding.

the cell's return to normal conditions, oxidoreductases reduce Hsp33's redox switch before its substrates are shifted to the ATP-dependent foldase DnaK/J/GrpE for refolding ${ }^{39,40}$ (Figure 2).

\section{RidA}

Another $\mathrm{HOCl}$-activated chaperone is the E. coli protein RidA, for which the chaperone activity has been mostly studied in vitro ${ }^{41}$. Interestingly, RidA, which normally functions as an enamine/imine deaminase involved in the synthesis of branched-chain amino acids ${ }^{42}$, loses its deaminase activity when incubated with $\mathrm{HOCl}$ while it turns into a holdase via the reversible $\mathrm{N}$-chlorination of positively charged residues, an unprecedented post-translational modification. N-chlorination makes the surface of RidA more hydrophobic, which activates its holdase activity ${ }^{41}$ (Figure 2). The fact that ridA mutant cells are more sensitive to $\mathrm{HOCl}^{41}$ suggests that RidA protects E. coli against $\mathrm{HOCl}$-induced damage. However, further investigation is required to determine the functional relevance of the $\mathrm{HOCl}$-induced chaperone activity of this protein in vivo and its potential role in the proteostasis network under $\mathrm{HOCl}$ stress.

\section{Cnox}

We recently identified CnoX as a novel type of protein folding factor that is essential for cell survival when $E$. coli is exposed to $\mathrm{HOCl}^{43}$. We demonstrated that $\mathrm{HOCl}$ turns $\mathrm{CnOX}$ into a powerful holdase by chlorination in a mechanism similar to that described for RidA ${ }^{41}$. Remarkably, CnoX can both function as a holdase and form mixed-disulfide complexes with client proteins. Under the latter role, CnoX prevents sensitive cysteine residues in its substrates from being irreversibly oxidized, which could otherwise have a detrimental effect on refolding and/ or block reactivation. Because $\mathrm{CnoX}$ can solve two problems faced by proteins (aggregation and overoxidation), it has become the first member of a new class of proteins: the chaperedoxins $^{43}$. Importantly, we established that, after stress, CnoX is capable of transferring its substrates not only to DnaK/ 
J/GrpE, like Hsp33 39 , but also to GroEL/ES, the only chaperone system essential for $E$. coli growth and survival ${ }^{44}$. This feature is conserved in the Caulobacter crescentus CnoX homologue $^{45}$ (Figure 2). CnoX is, to our knowledge, the first holdase shown to cooperate with GroEL/ES for protein refolding.

In addition to the proteins described above, work from the Jakob laboratory has led to the identification of PolyP, an inorganic polymer synthesized from ATP, as a chemical chaperone able to stabilize proteins during $\mathrm{HOCl} \operatorname{stress}^{46}$ (Figure 2). Accordingly, intracellular levels of PolyP increase during $\mathrm{HOCl}$ stress, as a result of both decreased hydrolysis ${ }^{46}$ and probably also increased synthesis, although this remains to be firmly established.

\section{Conclusions}

Whereas the important role for reducing enzymes, such as catalases, peroxiredoxins, thioredoxins, and glutaredoxins, in fighting oxidative stress in bacteria has been known for some time, the crucial function of $\mathrm{HOCl}$-induced chaperones for proteostasis has emerged more recently. The identification of an increasing number of these chaperones, in both prokaryotes and eukaryotes, raises a number of questions and hypotheses that will have to be addressed in the future. First, because activation by chlorination appears to be rather unspecific compared to activation by oxidation of cysteine residues, like in Hsp33, it is likely that additional proteins share the ability to be activated by $\mathrm{HOCl}$. Supporting this, it was recently reported that a number of proteins from human blood plasma are converted into holdases by $\mathrm{HOCl}$ via $\mathrm{N}$-chlorination ${ }^{47}$. Second, the identified stress-induced chaperones are expressed under non-stress conditions and are conserved in a large number of organisms, including non-pathogenic bacteria that are less likely to be exposed to high levels of $\mathrm{HOCl}$ in their natural environment. It is therefore tempting to speculate that these proteins display a basal function under normal conditions but evolved in certain organisms to act as chaperones under specific stress conditions. Focusing on the CnoX chaperedoxin expressed by the aquatic bacterium $C$. crescentus, we recently found that, in contrast to its $E$. coli counterpart, it functions as a thioredoxin and a constitutive holdase that does not need to be activated by $\mathrm{HOCl}$. Thus, within the family of CnoX proteins, only certain proteins (such as E. coli CnoX) have evolved to provide specific protection against $\mathrm{HOCl}$ stress $^{45}$. In the same line, it was recently shown that $\mathrm{N}$-chlorination does not activate the homolog of RidA from Staphylococcus aureus into a chaperone ${ }^{48}$. Thus, future work should determine the extent of the stress-induced chaperone network upon $\mathrm{HOCl}$ stress as well as the roles for these proteins under non-stress conditions and/or in non-pathogenic organisms.

\section{Abbreviations}

$\mathrm{H}_{2} \mathrm{O}_{2}$, hydrogen peroxide; $\mathrm{HOCl}$, hypochlorous acid; $\mathrm{O}_{2}^{--}$, superoxide radical; $\mathrm{O}_{2}$, molecular oxygen; $\mathrm{OH}$, hydroxyl radical; MPO, myeloperoxidase; PolyP, polyphosphate; ROS, reactive oxygen species.
1. Imlay JA: Cellular defenses against superoxide and hydrogen peroxide. Annu Rev Biochem. 2008; 77: 755-76.

PubMed Abstract | Publisher Full Text | Free Full Text

2. Kiley PJ, Storz G, et al.: Exploiting Thiol Modifications. PLoS Biol. 2004; 2(11) e400.

PubMed Abstract | Publisher Full Text | Free Full Text

3. Imlay JA: The molecular mechanisms and physiological consequences of oxidative stress: Lessons from a model bacterium. Nat Rev Microbiol. 2013; 11(7): 443-54.

PubMed Abstract | Publisher Full Text | Free Full Text

4. Ezraty B, Gennaris A, Barras F, et al.: Oxidative stress, protein damage and repair in bacteria. Nat Rev Micro. 2017; 15(7): 385-96. PubMed Abstract | Publisher Full Text

5. F Winterbourn CC, Kettle AJ, Hampton MB: Reactive Oxygen Species and Neutrophil Function. Annu Rev Biochem. 2016; 85: 765-92. PubMed Abstract | Publisher Full Text | F1000 Recommendation

6. Hurst JK: What really happens in the neutrophil phagosome? Free Radic Biol Med. 2012; 53(3): 508-20.

PubMed Abstract | Publisher Full Text | Free Full Text

7. Winterbourn CC, Kettle AJ: Redox Reactions and Microbial Killing in the Neutrophil Phagosome. Antioxid Redox Signal. 2013; 18(6): 642-60. PubMed Abstract | Publisher Full Text

8. F Thomas DC: The phagocyte respiratory burst: Historical perspectives and recent advances. Immunol Lett. 2017; 192: 88-96. PubMed Abstract | Publisher Full Text | F1000 Recommendation

9. Hawkins $\mathrm{CL}$, Davies MJ: Hypochlorite-induced damage to proteins: Formation of nitrogen-centred radicals from lysine residues and their role in protein fragmentation. Biochem J. 1998; 332(Pt 3): 617-25 PubMed Abstract | Publisher Full Text | Free Full Text
10. Hawkins CL, Pattison DI, Davies MJ: Hypochlorite-induced oxidation of amino acids, peptides and proteins. Amino Acids. 2003; 25(3-4): 259-74. PubMed Abstract | Publisher Full Text

11. Pattison DI, Davies MJ: Absolute Rate Constants for the Reaction of Hypochlorous Acid with Protein Side Chains and Peptide Bonds. Chem Res Toxicol. 2001; 14(10): 1453-64.

PubMed Abstract | Publisher Full Text

12. Bienert GP, Schjoerring JK, Jahn TP: Membrane transport of hydrogen peroxide. Biochim Biophys Acta. 2006; 1758(8): 994-1003.

PubMed Abstract | Publisher Full Text

13. Giorgio M, Trinei M, Migliaccio E, et al:: Hydrogen peroxide: A metabolic byproduct or a common mediator of ageing signals? Nat Rev Mol Cell Biol. 2007; 8(9): 722-8.

PubMed Abstract | Publisher Full Text

14. F Schürmann N, Forrer $\mathrm{P}$, Casse $\mathrm{O}$, et al.: Myeloperoxidase targets oxidative host attacks to Salmonella and prevents collateral tissue damage. Nat Microbiol. 2017; 2: 16268 .

PublMed Abstract | Publisher Full Text | F1000 Recommendation

15. Winterbourn CC, Hampton MB, Livesey JH, et al: Modeling the reactions of superoxide and myeloperoxidase in the neutrophil phagosome: implications for microbial killing. J Biol Chem 2006; 281(52): 39860-9. PubMed Abstract | Publisher Full Text

16. F Dahl JU, Gray MJ, Jakob U: Protein quality control under oxidative stress conditions. J Mol Biol. 2015; 427(7): 1549-63. PubMed Abstract | Publisher Full Text | Free Full Text | F1000 Recommendation

17. Gupta V, Carroll KS: Sulfenic acid chemistry, detection and cellular lifetime. Biochim Biophys Acta. 2014; 1840(2): 847-75. PubMed Abstract | Publisher Full Text | Free Full Text

18. Collet JF, Messens J: Structure, function, and mechanism of thioredoxin 
proteins. Antioxid Redox Signal. 2010; 13(8): 1205-16 PubMed Abstract | Publisher Full Text

19. F Degrossoli A, Müller A, Xie K, et al.: Neutrophil-generated HOCI leads to non-specific thiol oxidation in phagocytized bacteria. eLife. 2018; 7: pii: e32288. PubMed Abstract | Publisher Full Text | Free Full Text | F1000 Recommendation

20. F Xie K, Bunse C, Marcus K, et al.: Quantifying changes in the bacterial thiol redox proteome during host-pathogen interaction. Redox Biol. 2019; 21 101087.

PubMed Abstract | Publisher Full Text | Free Full Text | F1000 Recommendation

21. $\mathrm{F}$ Rosen $\mathrm{H}$, Klebanoff SJ, Wang $\mathrm{Y}$, et al.: Methionine oxidation contributes to bacterial killing by the myeloperoxidase system of neutrophils. Proc Natl Acad Sci U S A. 2009; 106(44): 18686-91.

PubMed Abstract | Publisher Full Text | Free Full Text | F1000 Recommendation

22. F Gennaris A, Ezraty B, Henry C, et al:: Repairing oxidized proteins in the bacterial envelope using respiratory chain electrons. Nature. 2015; 528(7582): 409-12.

PubMed Abstract | Publisher Full Text | Free Full Text | F1000 Recommendation

23. F Winter J, llbert M, Graf PCF, et al.: Bleach activates a redox-regulated chaperone by oxidative protein unfolding. Cell. 2008; 135(4): 691-701. PubMed Abstract | Publisher Full Text | Free Full Text | F1000 Recommendation

24. Barrette WC Jr, Albrich JM, Hurst JK: Hypochlorous acid-promoted loss of metabolic energy in Escherichia coli. Infect Immun. 1987; 55(10): 2518-25. PubMed Abstract | Free Full Text

25. Khor HK, Fisher MT, Schöneich C: Potential Role of Methionine Sulfoxide in the Inactivation of the Chaperone GroEL by Hypochlorous Acid $(\mathrm{HOCl})$ and Peroxynitrite (ONOO-). J Biol Chem. 2004; 279(19): 19486-93. PubMed Abstract | Publisher Full Text

26. Melkani GC, McNamara C, Zardeneta G, et al:: Hydrogen peroxide induces the dissociation of GroEL into monomers that can facilitate the reactivation of oxidatively inactivated rhodanese. Int J Biochem Cell Biol. 2004; 36(3): 505-18. PubMed Abstract | Publisher Full Text

27. Gray MJ, Wholey WY, Jakob U: Bacterial responses to reactive chlorine species. Annu Rev Microbiol. 2013; 67: 141-60.

PubMed Abstract | Publisher Full Text | Free Full Text

28. Gebendorfer KM, Drazic A, Le Y, et al.: Identification of a hypochlorite-specific transcription factor from Escherichia coli. J Biol Chem. 2012; 287(9): 6892-903. PubMed Abstract | Publisher Full Text | Free Full Text

29. Drazic A, Miura H, Peschek J, et al.: Methionine oxidation activates a transcription factor in response to oxidative stress. Proc Natl Acad Sci U S A. 2013; 110(23): 9493-8.

PubMed Abstract | Publisher Full Text | Free Full Text

30. Groitl B, Horowitz S, Makepeace KAT, et al:: Protein unfolding as a switch from self-recognition to high-affinity client binding. Nat Commun. 2016; 7: 10357. PubMed Abstract | Publisher Full Text | Free Full Text

31. F Jo KS, Kim JH, Ryu KS, et al:: Unique Unfoldase/Aggregase Activity of a Molecular Chaperone Hsp33 in its Holding-Inactive State. J Mol Biol. 2019; 431(7): 1468-80.

PubMed Abstract | Publisher Full Text | F1000 Recommendation

32. Barbirz S, Jakob U, Glocker MO: Mass spectrometry unravels disulfide bond formation as the mechanism that activates a molecular chaperone. $J$ Biol Chem. 2000; 275(25): 18759-66.

PubMed Abstract | Publisher Full Text

33. Jakob U, Muse W, Eser M, et al.: Chaperone activity with a redox switch. Cell.
1999; 96(3): 341-52

PubMed Abstract | Publisher Full Text

34. Jakob U, Eser M, Bardwell JC: Redox switch of hsp33 has a novel zinc-binding motif. J Biol Chem. 2000; 275(49): 38302-10.

PubMed Abstract | Publisher Full Text

35. Graf PC, Martinez-Yamout M, VanHaerents S, et al:: Activation of the redoxregulated chaperone Hsp33 by domain unfolding. J Biol Chem. 2004; 279(19): 20529-38.

PubMed Abstract | Publisher Full Text

36. Graumann J, Lilie $\mathrm{H}$, Tang $\mathrm{X}$, et al.: Activation of the redox-regulated molecular chaperone Hsp33--a two-step mechanism. Structure. 2001; 9(5): 377-87. PubMed Abstract | Publisher Full Text

37. Raman B, Siva Kumar LV, Ramakrishna T, et al.: Redox-regulated chaperone function and conformational changes of Escherichia coli Hsp33. FEBS Lett. 2001; 489(1): 19-24.

PubMed Abstract | Publisher Full Text

38. Won HS, Low LY, Guzman RD, et al.: The zinc-dependent redox switch domain of the chaperone Hsp33 has a novel fold. J Mol Biol. 2004; 341(4): 893-9. PubMed Abstract | Publisher Full Text

39. $\mathrm{F}$ Hoffmann $\mathrm{JH}$, Linke $\mathrm{K}$, Graf $\mathrm{PC}$, et al.: Identification of a redox-regulated chaperone network. EMBO J. 2004; 23(1): 160-8.

PubMed Abstract | Publisher Full Text | Free Full Text | F1000 Recommendation

40. Winter J, Linke K, Jatzek A, et al: Severe oxidative stress causes inactivation of DnaK and activation of the redox-regulated chaperone Hsp33. Mol Cell. 2005; 17(3): 381-92

PubMed Abstract | Publisher Full Text

41. Müller A, Langklotz S, Lupilova N, et al:: Activation of RidA chaperone function by $\mathrm{N}$-chlorination. Nat Commun. 2014; 5: 5804 PubMed Abstract | Publisher Full Text | Free Full Text

42. Lambrecht JA, Flynn JM, Downs DM: Conserved YjgF protein family deaminates reactive enamine/imine intermediates of pyridoxal 5'-phosphate (PLP)dependent enzyme reactions. J Biol Chem. 2012; 287(5): 3454-61. PubMed Abstract | Publisher Full Text | Free Full Text

43. Goemans CV, Vertommen D, Agrebi R, et al:: CnoX Is a Chaperedoxin: A Holdase that Protects Its Substrates from Irreversible Oxidation. Mol Cell. 2018; 70(4): 614-627.e7.

PubMed Abstract | Publisher Full Text

44. Horwich AL, Low KB, Fenton WA, et al:: Folding in vivo of bacterial cytoplasmic proteins: role of GroEL. Cell. 1993; 74(5): 909-17.

PubMed Abstract | Publisher Full Text

45. Goemans CV, Beaufay F, Arts IS, et al.: The Chaperone and Redox Properties of CnoX Chaperedoxins Are Tailored to the Proteostatic Needs of Bacterial Species. mBio. 2018; 9(6): pii: e01541-18 PubMed Abstract | Publisher Full Text | Free Full Text

46. F Gray MJ, Wholey WY, Wagner NO, et al:: Polyphosphate is a primordial chaperone. Mol Cell. 2014; 53(5): 689-99. PubMed Abstract | Publisher Full Text | Free Full Text | F1000 Recommendation

47. F Ulfig A, Schulz AV, Müller A, et al:: N-chlorination mediates protective and immunomodulatory effects of oxidized human plasma proteins. eLife. 2019; 8 pii: e47395.

PubMed Abstract | Publisher Full Text | Free Full Text | F1000 Recommendation

48. F Kim HJ, Kwon AR, Lee BJ: A novel chlorination-induced ribonuclease YabJ from Staphylococcus aureus. Biosci Rep. 2018; 38(5): pii: BSR20180768. PubMed Abstract | Publisher Full Text | Free Full Text | F1000 Recommendation 


\section{Open Peer Review}

\section{Current Peer Review Status:}

\section{Editorial Note on the Review Process}

Faculty Reviews are review articles written by the prestigious Members of Faculty Opinions. The articles are commissioned and peer reviewed before publication to ensure that the final, published version is comprehensive and accessible. The reviewers who approved the final version are listed with their names and affiliations.

\section{The reviewers who approved this article are:}

\section{Version 1}

\section{Ursula Jakob}

Department of Molecular, Cellular, and Developmental Biology, University of Michigan,, Ann Arbor, MI, USA

Competing Interests: No competing interests were disclosed.

\section{Haike Antelmann} Institute for Biology-Microbiology, Freie Universität Berlin, Berlin, Germany

Competing Interests: No competing interests were disclosed.

\section{Michael J. Gray} Department of Microbiology, School of Medicine, University of Alabama at Birmingham, Birmingham, Alabama, USA Competing Interests: No competing interests were disclosed.

\section{Lars I. Leichert}

Institute of Biochemistry and Pathobiochemistry, Microbial Biochemistry, Ruhr University Bochum, Bochum, Germany

Competing Interests: No competing interests were disclosed. 
The benefits of publishing with F1000Research:

- Your article is published within days, with no editorial bias

- You can publish traditional articles, null/negative results, case reports, data notes and more

- The peer review process is transparent and collaborative

- Your article is indexed in PubMed after passing peer review

- Dedicated customer support at every stage

For pre-submission enquiries, contact research@f1000.com 